\title{
Mengungkap Nilai-Nilai Kearifan Lokal Kediri Sebagai Upaya Pelestarian Budaya Bangsa Indonesia
}

\author{
Ita Kurnia \\ PGSD Universitas Nusantara PGRI Kediri \\ itakurnia@unpkediri.ac.id
}

\begin{abstract}
Indonesia is currently experiencing a national identity crisis. This is evidenced by the scientific study of the Indonesian Institute of Sciences (LIPI) that Indonesia is considered not ready to face the phenomenon of globalization in various aspects such as geography, economy, and culture. One effort that can be done by local communities as an effort to deal with the adverse effects of globalization is to use the values of local wisdom as a force. Local wisdom can serve as a filter for values that come from outside that are less suited to local cultural culture. This research is a qualitative research that express comprehensively some cases. The purpose of this research is to explore the potentials of local wisdom of Kediri people include (1) cultural background, (2) social background, and (3) agriculture and irrigation system in three subdistricts namely Kepung Subdistrict, Ngancar Subdistrict, and Semen Subdistrict. The results of this study indicate that (1) the majority of Kediri people are Javanese with strong Javanese custom by performing several rituals for nature conservation, (2) Kediri community social background with religious diversity but all goes well and peaceful and cultural preservation Strongly maintained, (3) the management of agricultural systems and irrigation society is very good and derived from generations of the Kediri kingdom proved by the existence of Harijing inscription.
\end{abstract}

Key words: local genius, Kediri communities, culture

\section{Pendahuluan}

Indonesia saat ini sedang mengalami krisis identitas kebangsaan. Hal ini dibuktikan berdasarkan kajian ilmiah Lembaga Ilmu Pengetahuan Indonesia (LIPI) bahwa Indonesia dinilai belum siap menghadapi fenomena globalisasi dalam berbagai aspek seperti geografis, ekonomi, dan kebudayaan.

Dalam kajiannya, LIPI menyurvei responden sebesar 4.561 orang untuk mengukur indeks kesiapan masyarakat di Sumatera Barat, Daerah Istimewa Yogyakarta, dan Sulawesi Selatan. Hasil survei menunjukkan masyarakat tiga provinsi itu relatif belum siap dalam menghadapi fenomena globalisasi. Ketidaksiapan tersebut dikawatirkan menimbulkan krisis dan konflik di dalam negeri. 
Pudarnya batasan budaya dan interaksi masyarakat menciptakan suasana borderless world yang merupakan situasi hilangnya batas-batas sosial yang dapat mengancam identitas bangsa. Negara yang tidak siap dalam menghadapi borderlessworld akan mengalami guncangan bahkan dapat menjadi ancaman keutuhan negara dalam jangka waktu panjang. Masih terbatasnya kesiapan masyarakat di daerah menghadapi era globalisasi membuat minimnya tindakan preventif yang dapat dilakukan untuk mencegah guncangan borderlessworld.

Salah satu usaha yang dapat dilakukan oleh masyarakat daerah sebagai upaya menghadapi dampak buruk globalisasi adalah menggunakan nilainilai kearifan lokal sebagai suatu kekuatan. Kearifan lokal dapat berfungsi menjadi penyaring bagi nilai-nilai yang berasal dari luar yang kurang sesuai dengan kultur budaya setempat.

Kearifan lokal (local wisdom) terdiri atas dua kata yaitu kearifan dan lokal (KBBI). Secara umum kearifan lokal dapat diartikan sebagai gagasangagasan setempat yang bersifat bijaksana, penuh kearifan, bernilai baik, yang tertanam dan diikuti oleh anggota masyarakatnya. Dalam disiplin Antropologi local wisdom dikenal dengan istilah local genius.Local genius merupakan istilah yang kali pertama dikenalkan oleh Quaritch Wales. Banyak antropolog yang membahas pengertian local genius, diantaranya Haryati Soebadio yang mengatakan bahwa local genius adalah juga local identity, identitas atau kepribadian budaya bangsa yang menyebabkan bangsa tersebut mampu menyerap dan mengolah kebudayaan asing sesuai watak dan kemampuan sendiri (Ayatrohaedi, 1986:18). Sementara Moendardjito (dalam Ayatrohaedi, 1986:40) mengatakan bahwa unsur budaya daerah potensial sebagai local genius karena telah teruji kemampuannya untuk bertahan sampai sekarang.

Ciri-ciri local genius adalah 1) mampu bertahan terhadap budaya luar; 2) memiliki kemampuan mengakomodasi unsur-unsur budaya luar; 3) mempunyai kemampuan mengintegrasikan unsur-unsur budaya luar ke dalam budaya asli; 4) mempunyai kemampuan mengendalikan; dan 5) mampu memberi arah pada perkembangan budaya. Kearifan lokal pada dasarnya teruji secara alamiah dan niscaya bernilai baik karena kebiasaan tersebut merupakan tindakan sosial yang berulang-ulang dan mengalami penguatan (reinforcement). Apabila suatu tindakan tidak dianggap baik oleh masyarakat, maka secara otomatis tidak akan mendapat penguatan secara terus-menerus. Pergerakan secara alamiah terjadi secara sukarela karena dianggap baik dan mengandung kebaikan menurut masyarakat setempat.

Secara filosofis, kearifan lokal merupakan cerminan perilaku budaya masyarakat yang berlatar belakang dari nilai-nilai kehidupan yang dianut oleh masyarakat secara turun temurun. Contohnya, dalam masyarakat Kediri menganut filosofi Jawa seperti Urip Iku Urup, Sura Dira Jayaningrat Lebur Dening Pangastuti, Aja Kuminter Mundak Keblinger Aja Cidra Mundak Cilaka, Alon-alon Waton Klakon, Nrimo Ing Pandum, dan lain-lain akan dimanifestasikan dalam menjalani kehidupan masyarakat Jawa. Selain itu nilai-nilai filosofis dan tatanan praktik kehidupan sehari-hari juga akan mempengaruhi kehidupan sosial. Contoh kehidupan gotong royong yang 
dipraktikkan dalam kehidupan masyarakat secara turun temurun akan memberikan inspirasi pada generasi berikut untuk melakukan hal yang sama. Potensi budaya tersebut merupakan potensi kearifan lokal yang perlu digali dan dikembangkan dalam masyarakat modern, terutama masyarakat Kediri.

Secara geografis Kabupaten Kediri terletak di belahan Selatan Provinsi Jawa Timur. Secara ekologis, wilayah Kabupaten Kediri diapit oleh dua gunung yang berlawanan sifatnya, yaitu gunung yang bersifat non vulkanik, gunung Wilis, di sebelah Barat dan gunung yang bersifat vulkanik, Gunung Kelud, di sebelah Timur. Di bagian tengah wilayah Kabupaten Kediri melintang aliran Sungai Brantas yang membelah wilayah menjadi dua bagian. Hamparan dataran rendah berupa daerah persawahan subur di sebelah timur sungai.

Kearifan lokal masyarakat Kediri menjadi sangat menarik untuk diteliti mengingat Kediri di masa silam merupakan daerah cikal bakal lahirnya kerajaan-kerajaan besar sekaligus menjadi payung bagi daerah-daerah dan kerajaan-kerajaan kecil di Jawa Timur. Pusat kerajaan baru di Jawa Timur muncul diantara dua masa berlangsungnya pemerintahan kerajaan di Jawa Tengah. Hal itu diketahui dari sebuah prasasti bertahun 729 saka (840 M) yaitu Prasasti Harinjing di Desa Siman Kecamatan kepung Kabupaten Kediri. Kearifan lokal masyarakat Kediri menjadi sebuah kajian yang akan dibahas lebih jauh, mengingat pentingnya menerapkan nilai-nilai kearifan lokal yang saat ini sudah banyak dilupakan banyak orang.

Pada abad ke-12 Kerajaan Kadiri dipimpin oleh seorang raja pertama yang bernama Sri Jayawarsa. Setelah Sri Jayawarsa mangkat dari kepemimpinannya, pemerintah Kadiri dipercayakan kepada putranya yang bernama Kamiswara. Pada masa ini, banyak bermunculan pujanggapujangga terkenal. Salah satunya adalah Mpu Dharmaja yang mengarang Kitab Semara Dahana dan Mpu Tanakung yang mengarang Kitab Lubdaka dan Kitab Wertansantya. Sepeninggal Kamiswara, Kerajaan Kediri dipimpin oleh Sri Jayabaya. Sri Jayabaya dikenal sebagai pujangga dan sering dihubungkan dengan buku-buku karangan beliau yaitu Jayabaya. Pada masa Sri Jayabaya hidup dua pujangga terkenal yaitu Mpu Panuluh yang kemudian menyelesaikan Kitab Mahabarata.

Pengungkapan nilai-nilai kearifan lokal masyarakat Kediri dibatasi tiga hal. Pertama adalah Prasasti Harinjing yang merupakan bukti keberhasilan Bhagawanta Bari dalam menjalankan sistem pertanian dan pengairan di wilayah Kediri. Kedua adalah Ritual Sesaji Gunung Kelud yang dilaksanakan oleh masyarakat desa lereng gunung Kelud tiap tahun. Kegiatan ini merupakan suatu bentuk kearifan budaya lokal yang bercermin pada salah satu legenda Kediri yaitu tentang Putri Kilisuci. Ketiga adalah Gereja Poh Sarang yang menggunakan gaya arsitektur Majapahit dalam membangun gedung.

Adapun alasan dipilihnya tiga kearifan lokal, yaitu Prasasti Harinjing, ritual Larung Sesaji, dan Gereja Poh Sarang karena masih minimnya penelitian dan pengetahuan masyarakat tentang kearifan lokal di Kediri. Kearifan lokal dianggap mampu mengatasi ketidaksiapan masyarakat dalam 
menghadapi era globalisasi dan diharapkan ada upaya untuk menggali dan mengembangkan kearifan lokal masyarakat Kediri sehingga kita tidak tergerus arus globalisasi.

Kearifan-kearifan lokal masyarakat Kediri tentu harus dilestarikan karena budaya tidak cukup hanya diceritakan saja melainkan harus diwariskan supaya tidak musnah. Nilai-nilai yang terkandung di dalam kearifan lokal masyarakat Kediri tentu bisa diintegrasikan ke dalam kehidupan sehari-hari sebagai salah satu cara melestarikan budaya setempat dan memperkenalkan kearifan lokal kepada generasi berikutnya.

Kabupaten Kediri pernah menjadi bagian berbagai kerajaan penting di Pulau Jawa. Penemuan prasasti Tondowongso di Kecamatan Gurah (15 km Timur Kota Kediri) pada awal tahun 2007 terindikasi merupakan kompleks pemukiman penting. Sejak perpindahan Kerajaan Medang dari Mataram ke timur menjelang milenium kedua, berdiri Kerajaan Kadiri atau Panjalu yang berlokasi di keraton Daha. Kerajaan Kadiri merupakan penerus Kerajaan Medang setelah pembagian wilayah sepeninggal Prabu Airlangga. Puncak kejayaan Kerajaan Kadiri adalah pada masa pemerintahan Raja Jayabaya.

Kabupaten Kediri secara geografis terletak di utara provinsi Jawa Timur. Letak astronomi Kabupaten Kediri berada diantara $111^{\circ} 47^{\prime} 05^{\prime}$ sampai dengan $112^{\circ} 18^{\prime} 20^{\prime}$ Bujur Timur dan $7^{\circ} 36^{\prime} 12^{\prime}$ sampai dengan $8^{\circ} 0^{\prime}$ 32' Lintang Selatan. Secara topografi Kabupaten Kediri terdiri atas dataran rendah dan pegunungan yang dilalui aliran sungai Brantas yang membelah dari Selatan ke Utara. Suhu wilayah ini berkisar antara $23^{\circ} \mathrm{C}$ sampai dengan $31^{\circ} \mathrm{C}$ dengan tingkat curah hujan rata-rata $1.652 \mathrm{~mm}$ per hari.

Luas Kabupaten Kediri sekitar 963,21 $\mathrm{km}^{2}$ atau 5\% luas wilayah Jawa Timur dengan jumlah penduduk pada akhir tahun 2010 tercatat ada 1.475.815 jiwa. Mayoritas penduduk Kabupaten Kediri adalah suku Jawa dan memeluk agama Islam.Kabupaten Kediri berbatasan dengan Kabupaten Nganjuk dan Kabupaten Jombang di sisi Utara, Kabupaten Jombang dan Kabupaten Malang di sisi Timur, Kabupaten Blitar dan Kabupaten Tulungagung di sisi Selatan, serta Kabupaten Tulungagung dan Kabupaten Nganjuk di sisi Barat.

Menurut data Badan Pusat Statistik (2015), masyarakat Kediri memiliki mata pencaharian sebagai petani , karyawan, pedagang, pengrajin/industri kecil, dan lain-lain. Kabupaten Kediri empat potensi daerah, yaitu perikanan, pertanian, perkebunan, dan produk-produk unggulan. Potensi perikanan mengembangkan beberapa sentra pembenihan serta budidaya ikan lele dan ikan koi.

Komoditas pertanian yang didominasi oleh produk tanaman pangan. Misalnya saja padi, jagung, ubi kayu, ubi jalar, kacang tanah, kedelai, sayurmayur, dan buah-buahan. Hasil pertanian yang merupakan produk unggulan Kabupaten Kediri adalah tebu, nanas, mangga Podang, dan lain-lain.

Tak kalah bersaing dengan produk pertanian, potensi perkebunan di Kabupaten Kediri juga memiliki komoditi yang bernilai tinggi. Misalnya tebu 
yang diproduksi di Kecamatan Wates, kelapa yang terdapat di Kecamatan Grogol, kapuk randu yang terdapat di Kecamatan Kandangan, tembakau di Kecamatan Purwoasri dan Papar, jambu mete di Kecamatan Plosoklaten, strawberi di Besuki, dan masih banyak yang lainnya. Selain hasil kebun, perkebunan di Kabupaten Kediri juga ada yang dijadikan sebagai spot tourism seperti perkebunan strawberi.

Potensi produk unggulan Pemkab Kediri adalah kelambu produksi Kecamatan Kunjang, sulam pita dan border produksi Kecamatan Purwoasri, kerajinan tempurung kelapa produksi Kecamatan Grogol, kerajinan pasir laut produksi Kecamatan Wates, tinta timbul untuk mengukir produksi Kecamatan Ngasem, tasbeh produksi Kecamatan Mojo, sapu sabut kelapa produksi Kecamatan Plemahan, dan masih banyak lagi. Wilayah pemasaran produk-produk unggulan ini tidak hanya lokal, tetapi sudah mencapai regional dan ada yang sudah menembus pasar dunia (Diskoperindag, 2011). Semua ini tak lepas dari sejarah Kabupaten Kediri yang memang terkenal akan produk pertanian yang terkenal sejak jaman kerajaan.Sebagai salah satu bukti adalah Desa Siman merupakan desa tertua yang berada di Kecamatan Kepung Kabupaten Kediri, Jawa Timur. Di desa Siman terdapat prasasti Harinjing yang merupakan monumen yang bertujuan untuk memberikan apresiasi kepada Bhagawanta Bari yang telah berjasa membangun dawuhan atau sistem irigasi yang terdiri atas saluran dan bendung atau tanggul di sungai Harinjing (masyarakat sekitar Desa Siman Kecamatan Kepung, Kediri menyebutnya Kali Serinjing).

\section{Metode}

Penelitian ini menggunakan pendekatan kualitatif dengan metode deskriptif. Penelitian kualitatif mengungkapkan secara komprehensif beberapa kasus yang relevan dengan tujuan penelitian (Stake, 1995) dengan kurun waktu penelitian selama sembilan bulan dimulai bulan Desember 2015 sampai bulan Agustus 2016.

Penelitian ini dilakukan di tiga tempat berbeda, yaitu 1. Larung Sesaji di Kecamatan Ngancar; 2. Gereja Poh Sarang di Kecamatan Semen; dan 3. Parsasti Harinjing di Kecamatan Kepung Kabpaten Kediri.

Teknik pengumpulan data yang digunakan dengan melakukan wawancara partisipan dan dokumentasi, adapun prosedur teknik analisis data dengan menggunakan analisis data interpretatif dengan pengecekan ulang oleh partisipan/member check (Lancy, 1993).

\section{Hasil dan Pembahasan}

\section{Latar Belakang Budaya}

Mayoritas masyarakat Kediri berasal dari suku Jawa. Oleh karena itu, masyarakat Kediri masih kental dengan adat Jawa pada umumnya, salah satunya adalah pelestarian budaya dalam rangka pelestarian lingkungan melalui sebuah ritual. Dalam masyarakat Jawa terdapat ritual yang berhubungan langsung dengan alam. Masyarakat Kediri juga mengenal ritual yang berhubungan dengan alam. Ritual tersebut dinamakan larung sesaji Gunung Kelud. Gunung Kelud dipercaya oleh masyarakat Kediri 
sebagai tempat yang sakral. Ritual Larung Sesaji ini dilakukan tiap tanggal 23 Suro (bulan dalam hitungan Jawa) dan digelar di Desa syarat dari Dewi Sugihwaras Kecamatan Ngancar Kabupaten Kediri.

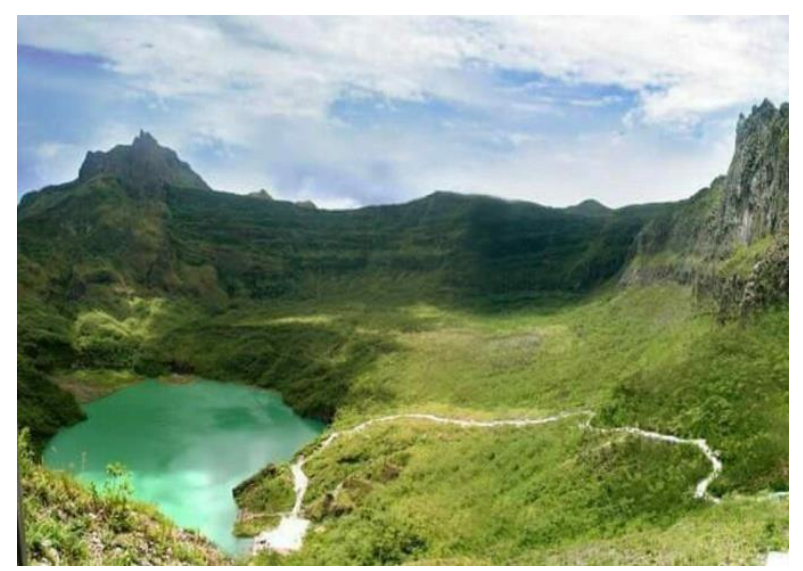

Gb. 2.1 Kawah Gunung Kelud

Larung sesaji Gunung Kelud merupakan ritual adat yang dilakukan tiap tahun di Kawah Gunung Kelud. Menurut cerita dari narasumber, ritual ini merupakan wujud rasa syukur kepada Sang Hyang Widhi oleh umat Hindu di Kediri. Selain itu, ritual ini juga digelar sebagai bentuk penghormatan pada penguasa Gunung Kelud dan untuk menolak balak sumpah Lembu Suro.

Menurut cerita narasumber, Gunung Kelud dalam legenda bukan berasal dari gundukan tanah yang meninggi secara alami. Seperti halnya Gunung Tangkuban Perahu di Jawa Barat, Gunung Kelud terbentuk dari sebuat cerita penghianatan cinta seorang putri bernama Dewi Kilisuci terhadap Lembu Suro. Dewi Kilisuci adalah putri Jenggolo yang terkenal akan kecantikannya.

Lembu Suro adalah legenda rakyat berwujud seorang pemuda berkepala kerbau. Dia adalah Raden Wimba, putera Adipati Blambangan yang dikutuk oleh sang Ayah karena kelakuan buruknya. Karena rupanya yang aneh tersebut, Dewi Kilisuci menolak lamarannya. Melalui Ayahnya, Dewi Kilisuci memberikan syarat yang berat untuk bisa meminangnya, yaitu dengan membuat sumur yang berbau wangi di puncak Gunung Kelud. Sumur tersebut rencananya akan dijadikan tempat mandi berdua seusai pernikahan dan harus selesai dalam waktu semalam, sebelum fajar.

Demi cintanya, Lembu Suro menyanggupi Kilisuci dan mengerahkan kesaktiannya untuk membuat sumur tersebut dan berhasil. Namun karena Dewi Kilisuci tidak juga bersedia menerima pinangan dari Lembu Suro, Dewi Kilisuci sekali lagi memberikan syarat, yaitu Lembu Suro harus masuk ke dalam sumur tersebut untuk membuktikan bahwa sumur tersebut berbau harum. Tanpa berpikir panjang Lembu Suro masuk ke dalam sumur untuk membuktikannya. Kemudian Dewi Kilisuci atas ijin Ayahnya memerintahkan prajurit Jenggala untuk menimbun Lembu Suro dengan batu.Maka matilah Lembu Suro terkubur bebatuan dalam sumur yang telah dibuatnya.

Sebelum mati, Lembu Suro bersumpah dengan mengatakan "Yoh wong Kediri mbesuk bakal pethuk piwalesku sing makaping-kaping, yoiku Kediri 
bakal dadi kali, Blitar dadi latar, tulungagung bakal dadi kedung (Ya, masyarakat Kediri besok akan mendapatkan balasanku yang sangat besar, yaitu Kediri akan menjadi sungai, Blitar menjadi daratan, dan Tulungagung akan menjadi danau). Lembu Suro juga bersumpah akan merusak tanah kerajaan Jenggolo setiap dua windu sekali. Mendengar sumpah Lembu Suro, Raja Jenggolo kemudian berinisiatif melakukan Larung Sesaji untuk menolak balak sumpah Lembu Suro.

Dari legenda tersebut akhirnya masyarakat Kediri, terutama masyarakat lereng Gunung Kelud, melakukan ritual Larung Sesaji untuk menolak balak dari sumpah Lembu Suro hingga sekarang. Selain itu juga ritual Larung Sesaji dijadikan sebagai wujud rasa syukur masyarakat lereng Gunung Kelud atas hasil pertanian yang melimpah oleh tanah yang subur.

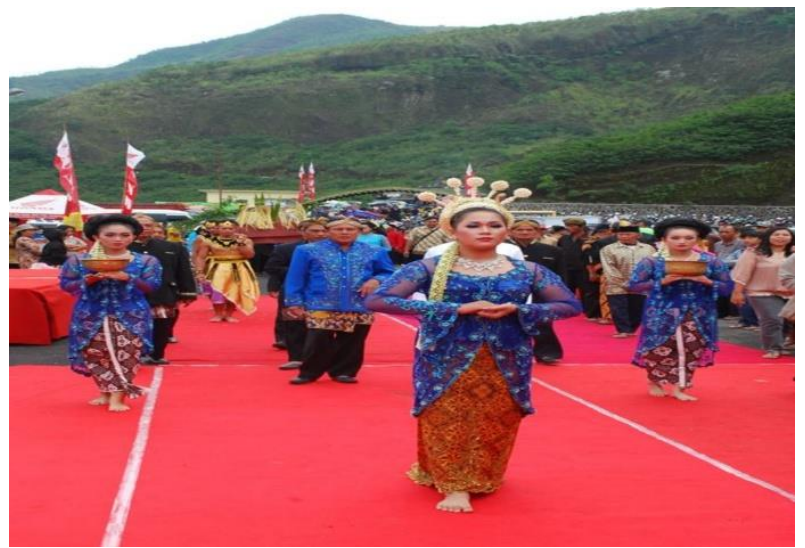

Gb. 2.2 Upacara Larung Sesaji

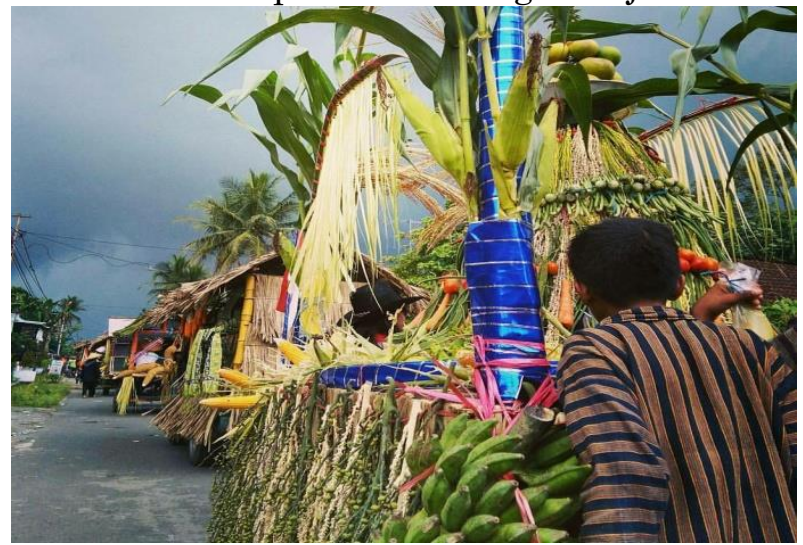

Gb. 2.3 Hasil Bumi sebagai sesaji

Ritual Larung Sesaji di kawah Gunung Kelud adalah dengan melarungkan hasil dari kegiatan manusia yang dilakukan di bumi atau alam. Ritual ini merupakan bukti adanya keseimbangan antara alam dan manusia. Masyarakat Kediri sangat menghargai alam dengan bentuk membalas budi berupa sesaji yang dilarungkan di kawah Gunung Kelud. Masyarakat Kediri meyakini bahwa melalui kegiatan ini alam dan manusia akan miliki kedudukan yang seimbang. Manusia akan selamat dari bahaya protes alam terhadap hal tidak baik yang dilakukan oleh manusia. dengan adanya ritual ini lahirlah toleransi agama yang sangat kuat dalam masyarakat Kediri. Hal ini dibuktikan bahwa masyarakat yang melakukan ritual ini tidak hanya dari kalangan agama Hindu dan Budha saja, melainkan seluruh umat dari 
agama lain. Dari peristiwa tersebut dapat disimpulkan bahwa meskipun masyarakat Kediri mayoritas beragama Islam, tetapi mereka mempunyai tujuan yang sama yaitu melakukan balas budi terhadap alam yang telah menyediakan fasilitas untuk manusia melakukan segala bentuk kegiatan.

Bagi masyarakat Jawa ini disebut $i b u$ bumi, bapa aksa, yang artinya bumi adalah simbol ibu yang memberikan kesuburan tanah sebagai tempat kegiatan pertanian. Dan langit adalah simbol bapak yang memberikan keberkahan berupa hujan. Ajaran ini sesuai dengan tujuan ritual Larung Sesaji yaitu mengajarkan kita bagaimana menyayangi, melindungi, dan menghormati bumi beserta langit sebagaimana kita melakukannya kepada orang tua. Jika kita merusak bumi, langit pun akan marah.

Ada beragam sesaji yang dibawa dalam ritual suci ini, seperti nasi, sayuran, lauk pauk, dan buah-buahan. Dalam ritual larung sesaji, masyarakat setempat biasanya membawa dua jenis tumpeng, yaitu tumpeng nasi putih dan nasi kuning. Tumpeng ini dilengkapi dengan aneka lauk pauk, seperti telur, tahu, tempe, urap, parutan sambal kelapa, dan masih banyak lagi. Menariknya, semua sesaji ditata sedemikian rupa sehingga tampak cantik.

Semua makanan yang dibawa oleh warga kemudian dikumpulkan di tengah. Mereka duduk mengelilingi sesaji sembari mendengarkan pemangku adat membacakan doa. Setelah selesai didoakan, hasil alam tersebut sebagian dilarungkan ke dalam kawah dan sebagian oleh warga dijadikan rebutan dengan harapan mendapatkan berkah dari doa pemangku adat berupa hasil pertanian yang melimpah. Dalam merebutkan sesaji ini tidak hanya warga masyarakat sekitar Gunung Kelud saja yang ikut serta, melainkan juga seluruh kalangan masyarakat, khusunya para penganut agama Hindu dari Bali, Yogyakarta, Surabaya, dan Semarang. Tradisi budaya ini menarik perhatian banyak orang yang tinggal di Kediri dan juga luar Kediri.

\section{Latar Belakang Sosial}

Kediri adalah kota yang majemuk. Namun demikian, mayoritas penduduk Kediri beragama Islam dan lainnya menganut Protestan, Katholik, Hindu, Budha, dan Konghucu. Meskipun demikian kerukunan antar umat beragama di Kediri terjalin sangat erat, sehingga dalam penyelenggaraan kehidupan sosial dapat berjalan lancar dan damai. Meskipun setiap pemeluk agama mendalami ajaran agama secara intensif, namun dalam hal melestarikan budaya tetap kuat.

Sebagai salah satu contoh bahwa antar umat beragama dalam masyarakat Kediri dapat hidup berdampingan dengan damai adalah dengan di bangunnya Gua Maria Lourdes di Desa Poh Sarang Kecamatan Semen Kabupaten Kediri. Sekitar 3000-an orang umat Katholik datang kesini, berziarah, berdoa di depan Gua Bunda Maria Lourdes.

Poh Sarang adalah nama sebuah desa yang berada di wilayah Kecamatan Semen, terletak di sekitar $10 \mathrm{~km}$ arah Tenggara Kota Kediri. Poh Keputih, tampaknya merupakan asal nama ini. Posisinya berada di lereng timur Gunung Klotok, Komplek Pegunungan Wilis, berupa kawasan berkontur, berudara dingin, dan batu kali menjadi kekayaan desa ini. Sungai Kedak 
yang melewati Poh Sarang dipenuhi batu, sehingga batu kemudian menjadi mata pencaharian kedua, selain bertani.

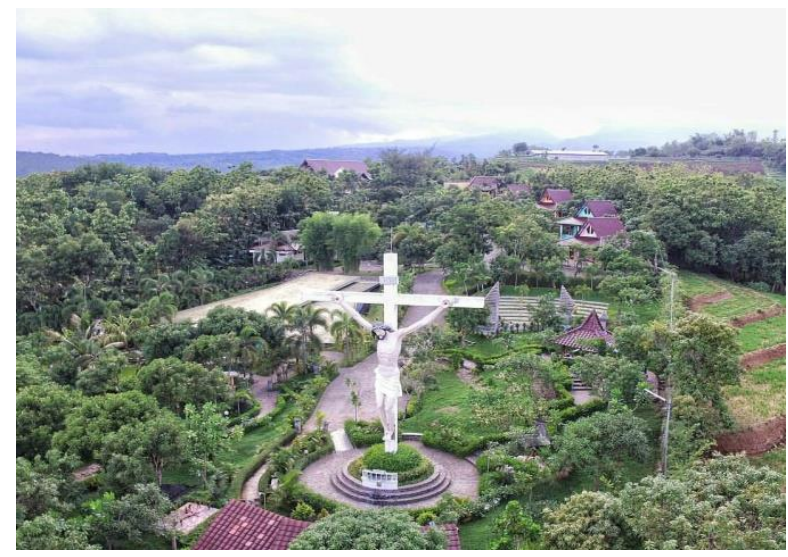

Gb. 2.4 Gereja Poh Sarang

Gua Maria Lourdes atau disebut juga Gereja Poh Sarang adalah gereja Katholik Roma oleh Ir. Henricus Maclaine Pont pada tahun 1936 atas permintaan pastor paroki Kediri pada waktu itu, yaitu Pastor H. Wolters, C.M. Insinyur tersebut juga menangani pembangunan Museum di Trowulan, Mojokerto, yang menyimpan peninggalan sejarah Kerajaan Majapahit. Karena didirikan oleh insinyur yang sama bangunan gereja Poh Sarang mirip dengan bangunan museum Trowulan, Mojokerto.

Di dalam area gereja terdapat mata air yang dipercaya oleh penduduk sekitar mampu menyembuhkan segala macam penyakit. Sebelum memasuki area mata air, di sepanjang jalan banyak pedagang yang menjual pernakpernik alat ibadah dan juga botol air. Tidak hanya umat Katholik, beberapa pemeluk agama lain juga terlihat mengambil air tersebut untuk berbagai keperluan. Inilah bentuk toleransi yang kuat oleh masyarakat Kediri dalam bidang sosial.

\section{Sistem Pertanian dan Irigasi}

Beberapa kerajaan Hindu-Buddha di Jawa Timur berkembang pada kondisi geografis yang didukung sungai Brantas tersebut yang juga didukung oleh peranan aktivitas Gunung Penanggungan. Sistem ekonomi kerajaankerajaan seperti Kediri, Singasari, dan Majapahit yang mencakup perdagangan pun lebih diuntungkan dengan akses penghubung yang lebih cepat dan aman antara daerah pedalaman dengan pesisir. Dengan perkembangan tersebut, maka beralihlah sistem agraris ke maritim. Namun, kerajaan Majapahit mampu memadukan keunggulan agrarisnya dan memperluas kekuatan maritimnya dengan memanfaatkan sungai Brantas sebagai penghubung ke laut lepas. Dengan adanya jalur tersebut, penerapan bea cukai dan upeti pun marak dilakukan ketika masa kerajaan Kediri hingga Majapahit. Dari beberapa perkembangan tersebut mengakibatkan munculnya kejayaan kerajaan Majapahit yang bertumpu pada sungai Brantas.

Gambaran mengenai budaya pertanian di Jawa sebelum kehadiran teknologi bercocok tanam modern oleh para kolonialis Eropa, hanya diketahui dari beberapa sumber data yang sangat terbatas, seperti prasasti, karya sastra 
Jawa Kuno, relief, baik yang bersifat artefaktual maupun tidak. Di antara sumber-sumber data tersebut, prasasti, karya sastra dan relief merupakan data yang cukup penting untuk merekonstruksikan budaya pertanian di Jawa.

Ada beberapa prasasti yang ditemukan di Jawa Timur yang dapat mengungkapkan kehidupan pertanian dari masa sejarah sebelum kehadiran sistem pertanian modern sebagaimana dianut sekarang. Beberapa prasasti tersebut adalah: Kwak I 879 M, Ngabean V (disebut juga Ra Tawun I) 883 M, Kamalagi 831 M, Watukura I 902 M, Harinjing 921 M, Bakalan (disebut juga Wulig) 934 M, Kamalagyan 1037 M, Prasasti Kandangan 1035 M, dan Trailokyapuri $1468 \mathrm{M}$.

Dari sumber prasasti-prasasti tersebut terdapat keterangan yang berhubungan dengan kehidupan pertanian, antara lain mengenai jenis-jenis pertanian, pejabat yang mengurusi soal pertanian, pajak-pajak pertanian, serta usaha-usaha yang dilakukan penguasa dalam memajukan sektor tersebut. Bahkan ada pula prasasti yang memuat keterangan mengenai proses bertani padi, mulai dari mengolah padi, mulai mengolah tanah, menyebar benih, menanam, menuai dan mengolah hasil pertanian. Keterangan yang serupa juga diperoleh dari karya-karya sastra Jawa Kuno.Sumber-sumber ini mencakup Kakimpoi Ramayana, Kitab Tantu Panggelaran, Kitab Arjunawiwaha, Sutasoma dan Pararaton. Keterangan lain yang melengkapi tentu adalah relief-relief, yang merupakan "foto" yang mengabadikan kehidupan pada masa lalu.

Berbicara mengenai jenis-jenis pertanian pada dasarnya dapat dibedakan menjadi: pertanian lahan kering dan lahan basah. Pertanian lahan kering adalah usaha bercocok tanam yang dilakukan pada tanah tegalan, di ladang atau kebun, sedangkan pertanian lahan basah adalah usaha bercocok tanam di lahan yang terendam air (sawah). Dari sumber sejarah, diketahui bahwa kedua jenis pertanian ini dikembangkan di Jawa. Jenis pertanian lahan kering lebih dulu dikenal, mungkin pada cocok tanam slash and burn yang dimulai sejak nenek moyang orang Jawa bermukim di pulau ini lebih dari 3.000 tahun lalu. Sedangkan bercocok tanam lahan basah dikenal setelah arus pendatang yang disebut kaum deutero-Melayu dari Taiwan dan Cina Selatan datang lewat laut ke Pulau Jawa, sekitar 1.000 sampai 3.000 tahun lalu.

Jenis-jenis tanaman yang dapat dibudidayakan di lahan kering berupa ladang (tegalan) jumlahnya lebih bervariasi. Tanaman di tegalan dapat menghasilkan tanpa adanya sistem pemberian air, irigasi atau pengairan, umumnya meliputi jenis umbi-umbian dan biji-bijian, termasuk jenis tanaman padi gaga (padi kering). Salah satu prasasti yang pertama kali menyebut adanya tanaman padi kering ini adalah Prasasti Watukura I 902 M. Jenis pertanian lahan kering lainnya adalah pertanian di kebun.Jenis pertanian di kebun ini dibedakan dari tegalan karena perbedaan letak.

Ladang atau tegalan letaknya terpisah dari tempat hunian (perumahan), sedangkan kebun adalah letaknya berdekatan dengan tempat hunian. Oleh karena itu, ladang biasanya lebih terbuka, sedangkan kebun lebih banyak 
ditumbuhi jenis tanaman peneduh dan atau sayur mayur. Kitab Arjunawiwaha, Pupuh 20 dan 21 menyebutkan di sekitar sebuah pertapaan ditanam buah kapundung (kepundung atau Baccaurea racemosa), duryan (durian atau Durio zibethinus Murr.), langsep (duku atau Lansium domesticum Corr.) dan pisang (Musa paradisa).

Pengetahuan masyarakat Kediri tentang lingkungan cukup luas. Interaksi antara alam dan manusia tidak lepas dari pandangan bahwa manusia harus mampu beradaptasi dengan lingkungan alam, mampu mengelola kekayaan alam, dan memanfaatkan kekayaan alam dengan bijaksana. Sejumlah fakta empiris menyebutkan bahwa sebagian masyarakat hidup dan memanfaatkan kekayaan alam yang dimilikinya. Pengalaman dan pengetahuan yang manusia dapatkan dari lingkungan melahirkan tindakan yang mereka sadari mengenai jenis-jenis sumber daya yang mereka miliki.

Berangkat dari pemahaman tersebut, masyarakat Desa Siman Kecamatan Kepung Kabupaten Kediri memiliki tradisi mengelola pertanian yang subur. Masyarakat Siman memiliki tanggung jawab yang maksimal untuk meneruskan tradisi tersebut untuk generasi yang akan datang. Keberhasilan pertanian masyarakat Siman dimulai sejak jaman kerajaan Kadiri. Hal ini dibuktikan dengan adanya Prasasti Harinjing.

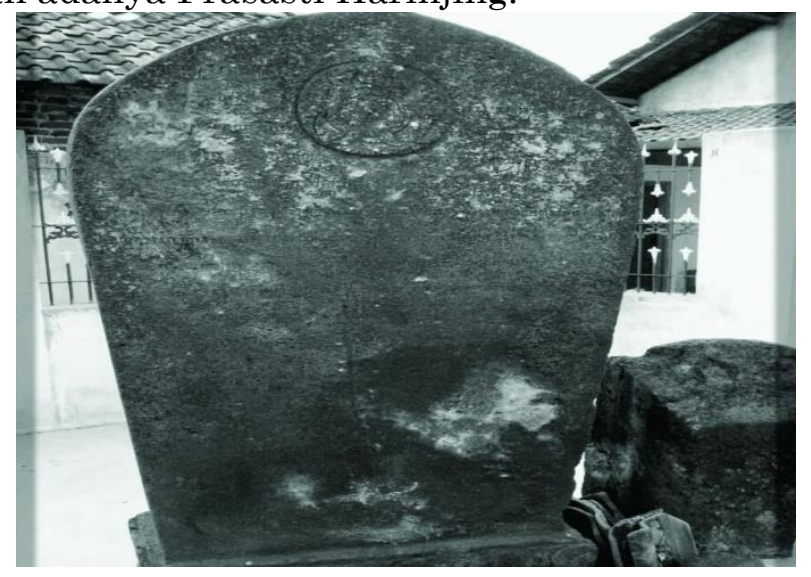

Gb. 2.5 Prasasti Harinjing B

Menurut narasumber, sebuah penelitian dulu pernah dilakukan oleh para ahli lembaga Javanologi seperti Bapak MM. Sukarton Kartoatmojo. Ada penyebutan nama Kadiri ada pada tiga prasasti Harinjing yang berada di Desa Siman, Kecamatan Kepung, Kabupaten Kediri. Prasasti tersebut terdiri atas tiga buah piagam yang ditulis dengan aksara dan bahasa Jawa kuno pada kedua sisinya. Bagian depan disebut Prasasti Harinjing A. Prasasti Harinjing A menyebutkan bahwa pada 11 Suklapaksa bulan Caitra tahun 726 Saka (25 Maret 804 Masehi) para pendeta di daerah Culanggi memperoleh hak sima (tanah yang dilindungi dari pajak) atas daerah mereka karena telah berjasa membuat sebuah saluran sungai Harinjing.

Bagian belakang disebut prasasti Harinjing B. Pada baris 1 sampai dengan 23 Prasasti Harinjing B menyebutkan bahwa Sri Maharaja Rake Layang Dyah Tulodong pada 15 Suklapaksa bulan Asuji tahun 843 Saka(19 September 921 Masehi) mengakui hak-hak para pendeta di Culanggi karena mereka masih tetap harus memelihara saluran Harinjing. 
Mulai baris selanjutnya, baris 24 hingga terakhir, pada bagian belakang disebut Prasasti Harinjing C. Prasasti ini menyebutkan bahwa hak serupa diakui pula pada 1 Suklapaksa bulan Caitra tahun 849 Saka (7 Juni 1015 Masehi).Isi dari ketiga prasasti Harinjing adalah tokoh dari desa Culanggi bernamakan Bhagawanta Bari yang memperoleh anugerah tanah perdikan dari Sri Maharaja Rake Layang Dyah Tulodong.Kiprah Bagawanta Bhari ketika itu, yaitu upaya untuk menyelamatkan lingkungan dari amukan banjir tahunan yang mengancam daerahnya tersebut.

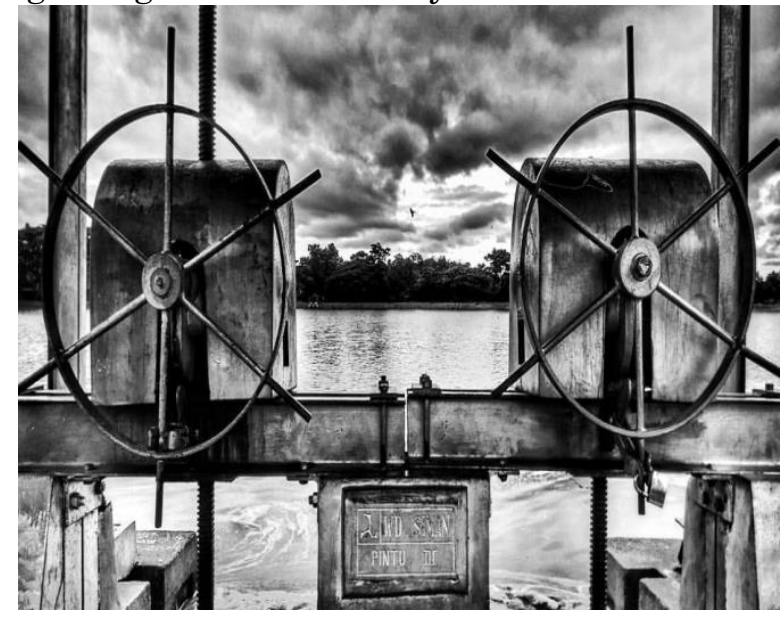

Gb. 2.6 Bendungan Waduk Siman

Prasasti Harinjing A adalah prasasti yang ditemukan paling tertua yang menyebut nama Kediri pada Maret 804 Masehi. Saat tersebut Kediri mulai disebut-sebut sebagai sebuah negara atau kerajaan karena merupakan daerah yang mandiri.Dalam prasasti Harinjing juga disebutkan pembangunan sistem irigasi (yang terdiri atas saluran dan tanggul) yang disebut dawuhan pada anak sungai Kali Konto, yakni Kali Harinjing. Kesuburan tanah sekitar sungai Brantas disebabkan adanya endapan material vulkanik dari beberapa gunung berapi yang aktif di bagian hulu sungai, yaitu Gunung Kelud dan Gunung Semeru.

\section{Kesimpulan}

Mengacu pada temuan penelitian dan pembahasan mengenai nilai-nilai kearifan lokal masyarakat Kediri sebagai upaya pelestarian budaya bangsa, maka dapat disimpulkan sebagai berikut:

1. Mayoritas masyarakat Kediri adalah suku Jawa yang kental dengan adat Jawa dengan melakukan beberapa ritual untuk pelestarian alam.

2. Latar belakang sosial masyarakat Kediri dengan keragaman agama yang dianut tetapi semua berjalan dengan lancar dan damai serta pelestarian budaya terjaga dengan kuat.

3. Pengelolaan sistem pertanian dan irigasi masyarakat sangat bagus dan didapat turun-temurun dari jaman kerajaan Kediri yang dibuktikan dengan adanya prasasti Harijing.

\section{Referensi}

BPS. 2015. Penduduk Kabupaten Kediri. Jakarta. 
Kementerian Kebudayaan dan Pariwisata Republik Indonesia. 2011. Buku Kearifan Lokal di Tengah Modernisasi. Pusat Penelitian dan Pengembangan Kebudayaan Badan Pengembangan Sumber Daya Kebudayaan dan Pariwisata Kementerian Kebudayaan dan Pariwisata Republik Indonesia. Jakarta. (Diakses 25 Desember 2015).

Manan, Imran. 1989. Perubahan Sosial Budaya, Modernisasi, dan Pembangunan. Jakarta: P2LPK.

Pidarta, Made. 2007. Landasan Kependidikan: stimulus ilmu pendidikan bercorak Indonesia. Jakarta: Rineka Cipta.

Samani, Muchlas dan Hariyanto. 2012. Konsep dan Model Pendidikan Karakter. Bandung: Remaja Rosdakarya.

Sartini. 2004. Menggali Kearifan Lokal Nusantara Sebuah Kajian Filsafat (dalam Jurnal Filsafat). (Internet). (Dikutip 25 November 2013): 37 (2): $111-120$.

Dapat diunduh di: http://www.search-document.com/pdf/1/1/MenggaliKearifan-Lokal-Nusantara-Sebuah Kajian-Filsafati.html.

Stake, Robert E. 1995. The Art of Case Study Research. Thousand Oaks, CA: Sage Publications.

Suhartini. 2009. Prosiding Seminar Nasional Penelitian, Pendidikan, dan Penerapan MIPA (16 Mei 2009). Yogyakarta. (Internet). (Diakses 25 Desember 2015)

Sukmadinata, , N.S. 2005. Metode Penelitian Pendidikan. Bandung: Remaja Rosdakarya.

Tim Penyusun. 2008. Kamus Besar Bahasa Indonesia. Jakarta: Pusat Bahasa.

--. 2008. Kamus Besar Bahasa Indonesia. Jakarta: Pusat Bahasa. 